\title{
THE UNITED STATES AND THE "LOSS" OF IRAN
}

by Barbara Zanchetta

\author{
WORKING PAPERS \\ in \\ INTERNATIONAL \\ HISTORY AND \\ POLITICS
}

No. 4 / June 2009 


\section{Working Papers}

in

International

\section{History and Politics}

Editor: Katrin Milzow

(C) Department of International History and Politics

Graduate Institute of International and Development Studies

Case postale 136 - 1211 Genève 21

http://graduateinstitute.ch/history-politics 


\section{Abstract}

This paper analyzes the crucial, albeit at times difficult, relationship between Washington and the last Shah of Iran, Mohammed Reza Shah Pahlavi. From the early 1950s to the late 1970s, Tehran's fundamental contribution to America's policy of global containment of the Soviet Union emerges as the central element of U.S. policy. Despite the mismanagement of Iranian internal affairs and the domestic problems which persisted throughout the decades, the American leaders constantly sought to secure a tight and positive relationship with the Shah. The events leading to the 1979 revolution and Washington's countermeasures are assessed within this context, pointing to America's erroneous perceptions and misjudgments of the local reality which resulted from a still rigidly Soviet-centric worldview. Finally, the paper indirectly tackles with the difficult question of what, if any, are the lessons and implications of this complex history for the future of U.S.-Iranian relations. 


\section{THE UNITED STATES AND THE “LOSS" OF IRAN}

The Shah's Iran is an island of stability in an otherwise unstable area which includes not only the broader Middle East but also the Persian Gulf

-- Kissinger to Nixon, April 1970

\section{Introduction}

Thirty years after the Islamic revolution of 1979, the relationship between the United States and Iran remains problematic and the future prospects unknown. The potential threat to the regional and global balance of power caused by Iranian nuclear ambitions has aroused deep concerns within the international community. However, in seeking to shape future policies towards Iran, many fail to recall that before the collapse of the Iranian monarchy, the United States (and, to a large degree, the "West" as a whole) had for decades relied on this country to guarantee the "friendly" orientation of this strategically vital region.

In exploring the motivations of the earlier alliance, this paper analyzes the relationship between Washington and the last Shah of Iran. The origins of the relationship are assessed in the first part of the paper. Attention will then focus on the key developments which took place during the 1970s. In fact, in the brief time span of one decade, America first irrevocably strengthened the alliance with the Shah and then was forced to acknowledge its demise in the aftermath of the Islamic Revolution. In this context, both the Nixon administration's decision to tighten U.S.-Iranian relations, and the loss of the partnership with the Shah during the Carter years, will be inter-related to the broader dynamics of the Cold War. 
While the paper focuses only on American policies, the underlining assumption is that the strategic importance of Iran was fundamental also for the general framework of Western security. Since the Second World War, European influence in the Middle East had steadily declined, mainly as a consequence of the weakening of the British and French ties to the region. This process became all the more evident in the late 1960s, after London's announcement of its decision to withdraw its presence from the Persian Gulf. In short, while the European countries sought to maintain independent policies (especially in their economic relationships), by the early 1970s the United States was (however reluctantly) recognized as the leader of the "free world" in the formulation of security policies towards the region. Consequently, America's alliance with Iran was crucial for securing also European interests - especially after 1973, when the West's vulnerability to the oil weapon became manifest. Therefore, even if America alone determined its policies towards Iran, the repercussions of the fall of the Shah inevitably impacted also on the conception of transatlantic security. By the late 1970s, both sides of the Atlantic in fact came to recognize that the traditional boundaries of the alliance between Europe and the United States were no longer sufficient to protect Western security, in itself defined more broadly.

\section{An Uneasy Partnership: U.S.-Iranian Relations, 1941-1969}

During the Second World War, Iran served as a strategically important "base" for the passage of Allied provisions en-route to the Soviet Union in support of the common anti-German war effort. Starting in late 1941, U.S. troops thus entered Iran for the first time, joining the British and Soviet occupation forces. Hence began America's troubled relationship with the young Mohammed Reza Shah who, aged 22, had replaced his father in ruling the country. After the end of the war, the crisis caused 
by Stalin's delay in withdrawing his forces signaled the importance that the emerging "Western camp" assigned to maintaining a predominant influence over Iran. ${ }^{1}$ In fact, as the Cold War gradually came to dominate the international scene, Britain and, increasingly, the United States tightened their relationship with the Shah, in the context of the general drive to contain the expansion of the Soviet Union.

However, the U.S. decision to "throw its support behind the Shah" created, from the start, "a crucial long-term cause of tension." ${ }^{2}$ Already in the late 1940s, Iranian nationalists started to criticize the United States for backing monarchical authoritarianism and for intervening in Iranian affairs with renewed forms of imperialism. Furthermore, while the "old" British imperial power had over time necessarily acquired extensive knowledge of Iran's culture and of its internal dynamics, the "new" American presence seemed to lack the experience and ability to interact with the complex local reality. ${ }^{3}$ These two elements: the unrelenting domestic dissatisfaction with the rule of the American-backed Shah and Washington's incapacity, or unwillingness, to acutely assess the Iranian internal situation remained constant critical features of the U.S.-Iranian relationship until the revolution of 1978-1979.

Yet, it is important to underline that despite some criticism from certain sectors of informed public opinion, until the 1953 CIAsponsored coup, the image exerted by the United States was still generally positive. America represented the ideals of democracy and modernization in a country struggling to emerge from underdevelopment, dominant external influence and authoritarian rule. In the immediate post-war years, anger and resentment was commonly directed against the British colonial "exploiters" who maintained their presence in Iran and, most importantly, administered the Anglo-Iranian Oil Company's rich revenues. In the early 1950s, Mohammed Mossadeq's reformist and nationalist movement emerged within this 
context, and strengthened itself under the determination to promote the autonomous development of Iran. The decision to nationalize the Oil Company was the obvious first step in reducing foreign involvement in Iranian affairs, while enabling the country to benefit from its own natural resources.

However, from the perspective of London and Washington, the economic setback combined with the widespread perception of political instability, potentially open to communist infiltration, triggered plans on possible "countermeasures." While initially the British and American leaders had been reluctant to intervene directly, with Churchill's return to power and the election of Eisenhower, the stage was set for "Operation Ajax" - the CIA covert intervention that ultimately led to the removal of Mossadeq and the consolidation of the Shah's openly pro-Western regime. ${ }^{4}$

From that moment onwards, the United States was able to secure both the existence of a friendly government, geared towards the containment of Soviet expansionism, and the penetration of the Iranian oil fields. In concrete terms, and from the standpoint of a superpower engaged in an increasingly global Cold War, the 1953 coup (the first "regime change" intervention of the U.S.-CIA) was, therefore, a clearcut success. At the same time, however, the coup inevitably, and irreparably, damaged the U.S.-Iranian relationship. Decades later, the words spoken by an Iranian woman are unequivocal: "Why did you Americans do that terrible thing? We always loved America. To us, America was the great country, the perfect country that helped us while other countries were exploiting us. But after that moment, no one in Iran ever trusted the United States again. I can tell you for sure that if you had not done that thing, you would never have had that problem of the hostages being taken in your embassy in Tehran. All your trouble started in 1953. Why, why did you do it?" 
Moreover, the events of 1953 deepened the fissure between the Iranian society and the Shah's autocratic rule, a rupture which would never be completely recomposed. Nevertheless, Washington progressively strengthened its relationship with Tehran. Starting in the mid-1950s, and especially after the 1958 anti-Western coup in Iraq, the U.S. aid program to Iran focused almost exclusively on reinforcing the country's military and defensive capabilities. After the proclamation of the Eisenhower Doctrine, and as the Middle East entered the Cold War "chessboard," the strategic importance of Iran, from the American viewpoint, became increasingly crucial. $^{6}$ Consequently, the U.S. governments continued to approve arms sales to Iran. Throughout the 1960s, Washington further developed its association with the Shah. For a combination of economic and geopolitical reasons, a positive relationship with Iran was in fact considered an essential asset in the formulation of policies towards the Persian Gulf.

Despite the problems of the agricultural sector and its narrowly based political regime, Iran's economic progress "under the leadership of an increasingly self-assured Shah" was deemed "remarkable." Between 1966 and 1969 the Iranian growth rate had proceeded at an annual rate of $10 \%$, without incurring inflation or substantial increases in debt. This performance had been made possible by the rapidly increasing oil revenues, which enabled public development programs and imports, with only minor strains on the country's foreign exchange position. ${ }^{7}$ In short, Iran was a "success story" among developing countries. ${ }^{8}$ This conveyed general optimism in the U.S. for the future continuation of the Iranian development and modernization process.

In addition, for Washington close ties with the Shah were valuable from a military and strategic point of view. Iran allowed transit rights for American military aircrafts, thus providing the U.S. and the Western democracies with a secure air corridor between European NATO and Southeast Asia. Also, the Shah's regime offered 
hospitality for vital communication and intelligence facilities, advantageously located close to the border with the Soviet Union. ${ }^{9}$

Finally, during the 1960s oil had emerged as essential for the security of the West. The dependence of Japan and Europe on the largest proven reserves of petroleum in the world rendered access to the Persian Gulf absolutely vital for the "free world." If the flow of oil was interrupted, or if it went under control of unfriendly countries, the repercussions for the Western industrial economies would be incalculable. From this perspective, the pro-Western orientation of the Shah's regime was obviously crucial. Furthermore, the British decision to withdraw its presence from the Gulf by 1971 added strategic significance to the region entailing, from Washington's standpoint, a greater commitment to its defense. ${ }^{10}$

\section{“Natural Allies" - Nixon and the Shah}

In the early 1970s, President Nixon therefore inherited a policy towards Iran which had been shaped by Washington's heavy reliance on the Shah's pro-Western and anti-communist credentials. This ensured a solid alliance deemed critical to U.S. security. However, the partnership with the Shah also had inherent difficulties. The Iranian leader's constant requests for arms sales and the general American reluctance in fully satisfying them caused continued, albeit concealed, tension. Against this background, the Nixon administration formulated its own line of action towards Tehran. While initially continuing the policies of his predecessors, in May 1972 Nixon opted to decisively strengthen the ties with the Shah. In this way, the pattern of restraint that had (with various degrees) previously characterized the American attitude towards arms sales was broken, thus irrevocably linking the United States to the Iranian leader. Significantly, these decisions took place in 
the immediate aftermath of the first Moscow summit between Nixon and Brezhnev, which marked the climax of U.S.-Soviet détente.

The basis of the U.S.-Iranian relationship during the Nixon years was the administration's increased reliance on local powers for the defense of areas considered vital to American national security. Although this policy - labeled as the Nixon Doctrine - had been originally formulated in relation to Vietnam (providing the framework for the withdrawal of U.S. troops), it rapidly evolved into the presidency's general posture towards the Third World. In its earliest formulation in relation to the Middle East (National Security Study Memorandum 66 of 1969), the policy recommended increased military and economic assistance to Iran and Saudi Arabia, the "two pillars" responsible for maintaining regional stability. Although Saudi Arabia was mentioned and would remain an important U.S. ally, Iran was clearly to become America's regional stronghold. ${ }^{11}$

The exchanges between the Iranian and American leadership confirm that the convergence of their policies was to a large extent motivated by the perception (either actual or crafted) of an external threat, i.e. coming from the Soviet Union directly or, most likely, by proxy. According to the Shah, Moscow was "trying to dominate the Mediterranean by establishing control over a triangle with its points at Suez, Aden and Djibouti." The broader objective was to access the Indian Ocean and, ultimately, the Persian Gulf. ${ }^{12}$ Moreover, the indication of rising radicalism in countries neighboring Iran offered opportunities to the Soviets to extend their influence. In particular, the Shah was concerned about the situation in Iraq. According to his assessment, the Soviets were supplying Baghdad with offensive armaments, including aircrafts, missiles and hardware. These shipments were significantly strengthening the Iraqi military capabilities. In addition, Moscow was pressuring Baghdad to include Iraqi communists in the composition of its future government. ${ }^{13}$ 
Within this context, the Shah believed that Iran could play a crucial role in maintaining radical Arab or Soviet influence at an "innocuous level."14 But this would require the further strengthening of his armed forces, with the additional acquisition of modern and sophisticated weapons. Despite the dangerous consequences that increased military investments could potentially entail - domestically, they would hinder the development of other sectors of the society, and internationally, they could alarm neighboring countries - the Shah was determined to follow his course. ${ }^{15}$ In concrete terms, this meant that the relations with the United States, Iran's chief provider of arms, would have to tighten more than ever before. It is thus not surprising that in early 1969 the Shah defined the United States and Iran as "natural allies." Consequently, he told U.S. National Security Adviser Henry Kissinger, it was vital for Washington and Tehran to coordinate their policies for "the next four, hopefully eight, years." ${ }^{16}$

The American viewpoint is effectively summarized in the many memorandums written to the President by Kissinger. At the beginning of the administration, Kissinger defined the Shah as a "man of mission," determined to modernize his country. To this end, he was "subtly pressing the idea of a 'special relationship' with the U.S." which would give Iran a preferred treatment, both in economic terms ${ }^{17}$ and on military credits. However, underlined the U.S. National Security Adviser, the Shah was not "entirely self-seeking." His commitment to the West was, in fact, assessed as "genuine." ${ }^{18}$ From this perspective, Kissinger referred to the Shah's definition of his country as an "island of stability" - a phrase which would become ill-famed in the later part of the 1970s.

However, during the first years of the administration, Nixon's and the Shah's potentially parallel views had not immediately translated into complete acquiescence to the Iranian leader's demands. While on surface the relationship remained positive and friendly, the 
pattern - requests from Tehran versus American reluctance in fully satisfying them - continued to cause tension. A general ambivalence, in fact, characterized the administration's posture. On the one hand, the strategic importance of Iran was acknowledged and underscored, while on the other, the emphasis was posed on limiting the Shah's requests (on the basis of cost, lack of urgency, undesirable precedent and other arguments). As anticipated earlier, President Nixon decided to resolutely strengthen the U.S.-Iranian relationship only in late May 1972. On his one and a half-day stop in Tehran en-route back to the United States from the Moscow summit, Nixon told the Shah that in the future virtually no more limitations would be placed on his purchases of American military equipment. With this decision the President overruled the conflicting recommendations of his advisers ${ }^{19}$ and, in essence, enabled Iran to enter with full title the circle of America's closest allies.

The significance of these decisions emerges in full only when the regional context is juxtaposed to the broader framework of U.S.Soviet relations. In fact, from Washington's standpoint, the perception of a greater need to resist Soviet expansionism into the region - actual or even only potential - was the central motivation for strengthening the alliance with Iran. As Kissinger stated in his memoirs:

The real issue in 1972 was that the required balance within an area essential for the security, and even more, prosperity, of all industrial democracies appeared in jeopardy. (...) Our friends - Saudi Arabia, Jordan, the Emirates - were being encircled.

It was imperative for our interests and those of the Western world that the regional balance of power be maintained so that moderate forces would not be engulfed nor Europe's and Japan's (and as it later turned out, our) economic lifeline fall into hostile hands. (...) To have failed to match the influx of Soviet arms into neighboring countries would have accelerated the demoralization of moderate forces in the Middle East and speeded up the radicalization of the area, including Iran's. ${ }^{20}$ 
For the U.S. leadership, it was thus vital to reassure the Shah on America's continued commitment to the defense of the pro-Western orientation of the area. Within this framework, the May conversations provided tangible evidence of Nixon's intention to firmly sustain Iran's role of anti-Soviet regional stronghold. In concrete terms, the President agreed to sell laser-guided bombs and F-14 and F-15 aircrafts, ${ }^{21}$ then both considered among the most advanced and sophisticated U.S.produced weapons. The third concession was the agreement on the assignment to Iran of an increased number of uniformed technicians, the so-called "blue suiters," to work with the Iranian military. In this way, Nixon gave weighty substance to the affirmation that he would not "let down" his friends. ${ }^{22}$

It is noteworthy to highlight also the particular timing of the May decisions. Such resolute strengthening of a de-facto alliance based on the containment and, if necessary, resistance to Soviet expansionism took place immediately after the first Nixon-Brezhnev summit in Moscow. While the "era of negotiation" produced landmark agreements (SALT I above all), at the same time the Nixon administration signaled to Iran and to the world that his innovative management of the relationship with Moscow did not entail potential American geo-strategic vulnerability.

Therefore, the ultimate strengthening of U.S.-Iranian ties was inherently related to the developments taking place on the broader bipolar "chessboard." In other words, the competition with the Soviet Union was the central element shaping Washington's worldview and, in this context, Iran was a crucial asset - an asset which became all the more important during the era of détente. This basic outlook remained decisive in the formulation of America's policy throughout the 1970s. Consequently, between 1972 and 1976 Iran continued to be the largest recipient of U.S. arms, purchasing almost one-third of total American sales. $^{23}$ The Ford administration maintained the basic guidelines of 
Nixon's policy and President Carter, in assuming office, displayed no intention of seeking a change of policy towards the Shah. ${ }^{24}$

\section{"The Island of Stability" - Carter and Iran}

Contrary to the promise of leading the country in a "new direction" and the declared "absolute commitment" to the promotion of human rights worldwide, ${ }^{25}$ Carter's attitude towards Iran revealed, from the start, a remarkable continuity with the policies of his so-bitterly criticized predecessors. $^{26}$ The incoming administration in fact demonstrated to assign more importance to American national security interests than to the values and principles posed at the center of Carter's electoral platform: neither the declared objective of opposing human rights abuses, nor the stated intention to focus on the local causes and dynamics of upheavals in the Third World, thwarted the development of U.S.-Iranian ties. Despite the growing instability of the Shah's regime, which faced inflation, unemployment and increasing criticism from many sectors of the civil society, during the first year of the Carter presidency, the close ties between Washington and the Iranian leader were repeatedly underscored. As a result, the Shah's preoccupations that Carter's human rights campaign would negatively impact on the development of the U.S.-Iranian relationship rapidly subsided. ${ }^{27}$

In May 1977, Secretary of State Cyrus Vance visited Tehran and informed the Shah on the decision to proceed with the sale of F-16 aircrafts and of the President's intention to seek approval for the sale of sophisticated airborne warning and control systems (the AWACS). During the November 1977 meetings in Washington, the President and the Shah once again acknowledged their special relationship and outlined an understanding on the need to continue to satisfy Iranian defense needs. It is interesting to note that while the Shah and his wife 
were welcomed at the ceremony, taking place on the White House lawn, Iranian students loudly demonstrated in the areas surrounding the White House. The police used tear gas to dispel the protests, causing embarrassment to the Carters and the Pahlavis, who had to hurriedly retreat inside. This incident notwithstanding, the Shah's visit proceeded as planned and was considered a diplomatic success by both sides. ${ }^{28}$ President Carter then paid a return visit to Tehran in December 1977..$^{29}$

The timing of what would be the last visit to Iran by an American president dramatically revealed the flawed perceptions, within the United States, on the Iranian domestic turmoil and on the capacity of the Shah to maintain control over the internal opposition. Carter flew to Tehran and praised the Shah at a time when his leadership was confronted with increasing antagonism. On December $31^{\text {st }}, 1977$, Carter declared:

Iran under the great leadership of the Shah is an island of stability in one of the more troubled areas of the world. This is a great tribute to you, Your Majesty, and to your leadership, and to the respect, admiration and love which your people give to you. ${ }^{30}$

Only a few weeks later, riots broke out in Tehran and in other major cities, starting the anti-regime demonstrations which would last, without interruption, until early 1979. With hindsight, the misjudgments of the Carter administration stand out because of the unfolding of the revolution and its related negative outcomes for the United States. However, it is important to underline that the overlooking of the Shah's problematic management of his domestic affairs had for decades been a constant feature of U.S. policy towards Tehran.

Although the American leadership was not blind to the problems in Iran, ${ }^{31}$ from the late 1950s onwards the concern with the 
Soviet Union and the increasing influence of oil outweighed all other considerations. In the early 1960s, the Kennedy administration, in line with its general approach to the Third World, had in part differentiated itself in its policies towards Iran, advocating internal development, social and economic reform over outright military assistance. The U.S. had thus cautiously favored the so-called "White Revolution" initiated by the Iranian leader - a broad, wide-ranging program intended to transform and modernize the Iranian society and economic structure. ${ }^{32}$

However, the Shah's reform programs were not received favorably domestically. Raising the expectations of the population while not producing the intended results, these policies only provoked further protests, while deepening the fissure between the regime and the society. Moreover, the United States, viewed in Iran as intrinsically related to the monarchy and to its failed promises, increasingly emerged as a target of the anti-regime demonstrations. With the Johnson administration entangled in Vietnam and less concerned about the Shah's management of his internal affairs, the Iranian leader tightened his repressive measures. This, in turn, inevitably produced louder protests and demonstrations (and, giving voice to the religious opposition, Ayatollah Khomeini emerged as a leading figure). In January 1965, Prime Minister Hassan Ali Mansur was killed and later that year the Shah himself survived an assassination attempt (the investigation later pointed to the left-wing middle class intellectual opposition to the regime).

These events, which evidently unveiled the increase of the Iranian domestic unrest, could have - and should have - been warning signs for the United States. But they were not. In the early 1970s, the Nixon administration not only continued to develop the relationship with Iran but, as illustrated above, decided to strengthen the link with the Shah to an unprecedented degree. 
There is ample evidence that between 1969 and 1972 reports on the instability in Iran had been compiled and had reached the U.S. leadership, which, however, repeatedly disregarded them. In February 1970, for example, American Ambassador in Tehran Douglas Mac Arthur cabled Washington on riots and clashes of protesters against the government but, at the same time, claimed that these did not affect the Shah's popularity. ${ }^{33}$ Later that year, the Ambassador himself was the target of an attack. The incident, deliberately kept secret, revealed the by then tangible anti-Americanism present within the Iranian society. ${ }^{34}$ In May 1971, Mac Arthur again reported student demonstrations against the Shah and the "White Revolution" and stated that these protests were becoming more frequent and increasingly radical. While outside interference may have contributed to instigate them, the complaints mainly centered on the inequality of the regime and emerged, for the most part, from within the country. ${ }^{35}$ On the other hand, a month earlier, in a private conversation with President Nixon, Mac Arthur had praised the Shah's rule as "strong" and "sound" and optimistically assessed the results of his "great social revolution." 36 The disparity between the optimistic assessments on the American part and the evolution of the local instability is, therefore, evident. Numerous reports on popular discontent continuously arrived up until a few weeks before Nixon's decisive visit in May 1972. ${ }^{37}$ But despite these, Iran continued to be considered an "island of stability in an otherwise unstable area." ${ }^{38}$ On this basis, Nixon proceeded to further and decisively strengthen the partnership with the Shah.

Washington's apparent disconnection from reality can be partially attributed to the particular nature of the U.S.-Iranian relationship which, though tight and positive was, on the Shah's part, never regarded as entirely reliable. If on the one side the Iranian leader was indebted to the U.S./CIA for restoring him to power in 1953, on the other he remained suspicious that, should the domestic situation 
appear as uncontrollable, the U.S. might decide to intervene also against him. Thus, the Shah not only sought to strengthen his country's military, which would allow as much margin of independence as possible (even from Washington), but also maneuvered to isolate American officials from the Iranian population and civil society. Consequently, the volume of CIA political reporting on internal developments in Iran during the early 1970s dropped below that of the late 1940s. The U.S. Embassy in Tehran had few officials who could speak Farsi, or who had had previous experience in Iran. ${ }^{39}$ Hence, by the mid-1970s, as later admitted by Secretary of State Cyrus Vance, the American knowledge of the opposition to the Shah was "sketchy." 40

The misperceptions and erroneous judgments of the Iranian internal turmoil became all the more manifest in the late 1970s. In August 1977, for example, the CIA concluded a sixty-page study with the statement that "the Shah will be an active participant in Iranian life well into the 1980s" and that "there will be no radical change in Iranian political behavior in the near future." ${ }^{41}$ A year later, a fire broke out at the Cinema Rex in the city of Abadan, killing hundreds of people. This episode triggered the escalation of the popular protest against the Shah's regime. In early September 1978, the Iranian leader tightened his fist and declared martial law, cracking down on the demonstrators in Tehran. Hundreds were killed on what became known as "black Friday," today considered a turning point in the unfolding of the Iranian revolution. ${ }^{42}$ In spite of these events, in late September 1978 the DIA reported that the Shah was "expected to remain actively in power over the next ten years." ${ }^{43}$ In November 1978, in his weekly report to the President, Brzezinski wrote: "Good news! According to a CIA assessment (..) Iran is not in a revolutionary or even a prerevolutionary situation." ${ }^{44}$ President Carter's public statements were along the same lines. On December 12, 1978 he stated: "I fully expect the Shah to maintain power in Iran and for the present problems in Iran 
to be resolved." ${ }^{45}$ A month later, on January 16, 1979, the Shah left Iran, never to return. From the American standpoint, the "island of stability" had suddenly and unexpectedly crumbled.

\section{The "Loss" of Iran - America and the Iranian Revolution}

According to Brzezinski, "Iran was the Carter administration's greatest setback. The fall of the Shah was a disaster for the United States strategically and politically for Carter himself." The U.S. National Security Adviser then added: "Perhaps that disaster was historically inevitable, the Islamic fundamentalist wave too overpowering." ${ }^{46}$

Apart from determining the "inevitability" of the revolution ${ }^{47}-$ a questionable exercise in itself after the course events - it is important to emphasize that, as the opposition against the Shah mounted and the instability of the regime gradually became manifest, Washington viewed the Iranian upheaval exclusively within the framework of the Cold War. Notwithstanding Brzezinski's reference to the "Islamic fundamentalist wave," the analysis of the administration's reaction to the unfolding of events confirms that the focus of attention was on the global repercussions of the "setback" (i.e. on the Soviet Union) and not on the evolution of internal dynamics (which, with hindsight, proved to have much more far-reaching implications than the Soviet threat). In other words, President Carter, in line with his predecessors, considered Iran a key cornerstone of regional stability and this aspect, to a large extent, overshadowed all others. With the predetermined priority set on defending a solid anti-Soviet strategic ally, Carter's foreign policy team - in itself deeply divided ${ }^{48}$ - not only completely overlooked the causes of Iran's domestic turmoil but, ultimately, failed to understand the complex roots of the grievances against the Shah.

From this perspective, some of the administration's internal assessments are revealing. In December 1978, Brzezinski pointed to the 
area defined as "the arc of crisis" ${ }^{49}$ and referred to the situation in Iran with extreme concern, drawing a parallel with the late 1940s:

There is no question in my mind that we are confronting the beginning of a major crisis, in some ways similar to the one in Europe in the late 40 's. Fragile social and political structures in a region of vital importance to us are threatened with fragmentation. The resulting political vacuum might well be filled by elements more sympathetic to the Soviet Union. (...) If the above analysis is correct, the West as a whole may be faced with a challenge of historical proportions. ${ }^{50}$

According to Brzezinski, such momentous developments required a major adjustment of policy, entailing long-term solutions as well as more direct security commitments. As the turmoil in Iran neared its climax, he associated the events in Iran to those in Afghanistan, calling for a comprehensive American response:

With regards to the arc of instability along the Indian Ocean, we need to respond collectively (...).The disintegration of Iran, with Iran repeating the experience of Afghanistan, would be the most massive American defeat since the beginning of the Cold War, overshadowing in its real consequences the setback in Vietnam. ${ }^{51}$

Although the State Department professionals did provide analyses on the internal dynamics of the revolution, by 1979 Brzezinski's position within the administration had become dominant and the President closely followed the advice of his National Security Adviser. The Soviet-centric view of world affairs, initially criticized and repudiated, increasingly came to dominate the Carter administration's policy choices.

From Washington's standpoint, the fall of the Shah deprived the United States of its main strategic "pillar" in the Persian Gulf. The collapse of the regime also signified the impossibility of maintaining intelligence surveillance stations to monitor military developments in 
Soviet territory, sites which had been considered irreplaceable by the American intelligence community. ${ }^{52}$ Moreover, no other country could replace Iran in guaranteeing Western influence in the region. ${ }^{53}$ As a consequence, the United States started to broadly rethink its role. With the prospect of no longer being able to rely on Iran, Washington needed to enhance its own direct presence and its military capabilities in the Gulf, assuming directly the responsibility previously devolved to the Shah. In February 1979, Secretary of Defense Brown's statements disclosed the shift in America's policy:

We have made a policy decision about a more active role in the area. We told these countries things that they have not heard for a long time - namely, that the United States is deeply interested in the Middle East, we are very worried about what the Soviets are doing, we intend to be involved. That's a line no American administration has taken with them since Vietnam..$^{54}$

A few days later, Brown announced on television that the U.S. would be prepared to defend its vital interests in the Middle East with whatever means appropriate, including military force. ${ }^{55}$ In his March 1979 report to the President, Brzezinski outlined the unfavorable (from the American point of view) developments in the so-called arc of crisis:

The coup in Afghanistan, the Soviet-Cuban presence in Ethiopia, and improved communist party position in South Yemen open up the possibility of new Soviet threats not only to Iran but also to smaller Persian Gulf States, Saudi Arabia, and North Yemen. As the surprisingly rapid disintegration of the Pahlavi regime in Iran indicates, all of these states are likely subjects for political instability, which could offer the Soviets various opportunities to expand their influence.

And, most importantly, Carter's National Security Adviser spelled out a comprehensive U.S. strategy to prevent Moscow's potential advancement into the region, which included: 
1.continued efforts to maintain as much access as possible to current regimes in Ethiopia and Afghanistan (as well as Iraq and South Yemen);

2. clarification of US interest in the stability of the area and of the seriousness with which we could view any Soviet efforts to expand their influence in proWestern countries;

3.technological assistance and political support designed to strengthen current pro-Western regimes in the area;

4. rapid implementation of the PD- $18^{56}$ provisions concerning a quick reaction force;

5. increasing US military presence in the Persian Gulf area;

6. reconstitution of CIA covert action capabilities in the area. ${ }^{57}$

Reflecting on Brown and Brzezinski's words, which to a large degree are representative of the dominating view within the administration, two elements emerge with clarity: first, the repeated references to Vietnam confirm the almost exclusive focus on preventing another major setback, exclusively assessed in terms of the bipolar competition. Second, both the commitment to a greater involvement in the region, potentially entailing a military presence, and the strategy outlined by Brzezinski, anticipated the definite shift of policy made public in early 1980 with the proclamation of the Carter Doctrine.

Although the Soviet invasion of Afghanistan in December 1979 added urgency to the redefinition of America's posture, the basic change of approach, which led to a firm commitment to the defense of the region, took place as a consequence of the loss of Iran. In the months that followed the collapse of the Shah's regime, the Carter administration in fact made concrete moves to expand its role throughout the arc of crisis. In March 1979 the U.S. decided to provide military assistance to North Yemen ${ }^{58}$ and in July 1979 Carter authorized the CIA to supply assistance to the rebels fighting in Afghanistan. ${ }^{59}$ 
Moreover, the administration proceeded with the creation of a rapid deployment force. ${ }^{60}$ Finally, in January 1980, the President declared that "any attempt by any outside force to gain control of the Persian Gulf region will be regarded as an assault on the vital interests of the United States of America, and such an assault will be repelled by any means necessary, including military force." ${ }^{\prime 1}$ Clearly, this statement (later labeled as the Carter Doctrine) resulted from a reassessment of American regional policy which had been taking place for almost a year. Ultimately, it represented the utmost confirmation that the containment of the Soviet Union remained the central aspect of U.S. foreign policy.

In the administration's internal assessments (and in its public pronouncements) no reference was made to the long term implications of the birth of the Islamic Republic, although the drama of hostage crisis should have imposed a reflection on the deeply rooted antiAmericanism of the new regime. Although Khomeini was an outspoken anti-communist (as well as anti-imperialist), the American leadership continued to disregard the local component and remained focused on Moscow's potential advancement into the Persian Gulf. The anti-Soviet response promptly shaped America's shift in policy, while specific countermeasures towards the emergence of Islamic fundamentalism seemed not be conceived.

In this context, the words written in 1983 by Cyrus Vance (the member of the administration most sensitive to considering issues in their own right and not as elements to be manipulated in the confrontation with the Soviets) confirm the then almost unanimous bias of American foreign policy-makers:

At this writing, an evaluation of the long-term consequences of the Shah's fall cannot be made. That will depend on what happens in the power struggle that is likely to follow the death of Khomeini. If a durable, non-Communist regime emerges, it is probable there will be 
an improvement in U.S.-Iranian relations based on our common interests in a secure, united and prosperous Iran. If, however, Iran slides into a civil war, the temptation will exist for the Soviet Union to fish in the troubled waters (...). If this should happen there would be grave danger of a U.S.-Soviet confrontation. ${ }^{62}$

As we now know, a durable non-Communist regime did consolidate itself in Iran and there (happily) never was a U.S.-Soviet confrontation. However, after three decades, U.S.-Iranian relations have yet to concretely improve.

\section{Conclusions}

Considering the Cold War context and the strategic location of Iran, it is perhaps logical that the concern with the Soviet Union would dominate Washington's policies towards Tehran. In essence, Iran provided a fundamental contribution to the broader U.S. strategy of containment. America's disinterest, or even neglect, of Iranian internal affairs was the consequence of this seemingly unavoidable global bias. For the United States there simply were more important considerations than those related to the internal dynamics of the Iranian regime.

While this attitude in general characterized the U.S.-Iranian relationship, the overlooking of the complex regional reality had particularly far-reaching consequences during the 1970s. Despite the unequivocal signs of the growing domestic unrest, the Nixon administration proceeded with the strengthening of the link with the Shah. The increased reliance on Iran was, in fact, a crucial aspect of Nixon's innovative foreign policy. In an era of acknowledgement of limits, America delegated responsibilities while at the same time emphasizing that the continued priority was to resist Soviet expansionism.

Paradoxically, Washington's Soviet-centric view emerged all the more clearly during the Carter presidency - the administration that 
more than any other had criticized the excessive centrality of the Soviet Union in the formulation of American foreign policy. To a large extent, precisely because of the bias in viewing the Iranian upheaval in terms of a global setback, the U.S. leadership failed to assess the complexity of the Iranian revolution. This is confirmed by America's reaction to the events, which focused on defining a new strategic posture to face the perceived increased Soviet challenge.

The heightened sense of American vulnerability caused by the events of 1979 had repercussions also on the overall concept of Western security. Until the late 1970s, the transatlantic alliance had not explicitly recognized that "out of area" issues (i.e. developments taking place outside the boundaries of the member countries of the North Atlantic Treaty) could directly undermine NATO security. However, after the Iranian revolution and the Soviet invasion of Afghanistan, the search for an Allied approach to the Persian Gulf necessarily brought the out of area question to the forefront of NATO's policies. For the first time, the final communiqué of NATO's Defense Planning Committee issued in May 1980 formally recognized that "the stability of regions outside NATO boundaries, particularly in South West Asia, and the secure supply of essential commodities from this area are of crucial importance (...) the current situation has serious implications for the security of member countries." ${ }^{63}$ The two obvious reasons for concern were the need to secure the flow of oil and the Soviet advance into Afghanistan, which highlighted the West's potential exposure in the area. It is not difficult to argue that both these factors would have had far less negative and far-reaching implications for NATO countries had the Iranian regime continued to function as a solid pro-Western asset. In short, therefore, the loss of Iran was not just an American loss.

Although it is difficult to draw lessons from the intricate history of U.S.-Iranian relations, the issues studied in this paper could trigger a reflection on the overall exercise of American power. While 
former presidents Nixon and Carter have rarely been citied to have something in common, their policies towards Iran were clearly shaped by analogous motivations. Both considered Iran a strategically crucial ally in the Cold War context of global rivalry with the Soviet Union. And both failed to foresee the inherent fragility of America's regional stronghold. It is curious (though more than just symbolic) to point out that the two administrations also referred to the same words to define Iran - an "island of stability" - which today sound, to say the least, ironically shortsighted.

Even such apparently opposite presidencies thus shared a basically flawed and limited vision. Over-riding Cold War concerns constantly dictated American policy, to the detriment of a more in depth understanding of complex local realities. Could this be one of the problematic legacies of the turbulent 1970s? At a minimum, the reflection on the loss of Iran should caution the United States and its Allies against excessive great power biases, particularly considering today's even more multifaceted regional and global dynamics.

Barbara Zanchetta

Academy of Finland Research Fellow, University of Tampere 


\section{Notes}

${ }^{1}$ On the Soviet withdrawal crisis see, for example: Kenneth M. Pollak, The Persian Puzzle. The Conflict between Iran and America (New York: Random House, 2004), 44-48.

${ }^{2}$ James A. Bill, The Eagle and the Lion. The Tragedy of American-Iranian Relations (New Haven: Yale University Press, 1988), 49.

${ }^{3}$ According to James Bill, the "American ignorance of Iran was embarrassingly evident at all levels;" Bill, The Eagle and the Lion, 42.

${ }^{4}$ For a comprehensive account of the 1953 coup against Mossadeq: Stephen Kinzer, All the Shah's Men: An American Coup and the Roots of Middle East Terror (Hoboken: Wiley, 2003). See also: Pollack, The Persian Puzzle, 63-71; Bill, The Eagle and the Lion, 72-97 and the New York Times online: http://www.nytimes.com/library/world/mideast/041600iran-ciaindex.html.

${ }^{5}$ Kinzer, All the Shah's Men, ix.

${ }^{6}$ The Eisenhower Doctrine, proclaimed in a special message to Congress in January 1957, formally extended the U.S. strategy of containment to the Middle East. To sustain America's role in the region, the U.S. supported the Baghdad Pact, signed in 1955, which included Turkey, Iran, Iraq, Pakistan, Great Britain and ended in 1958 following the coup in Iraq. The Baghdad Pact evolved into CENTO, signed in 1959, which included Turkey, Iran, Pakistan and the United States. These alliances signaled America's increased interest in the region.

7 National Intelligence Estimate 34-69, Washington, January 10, 1969, FRUS, Foreign Relations, 1969-1972, Volume E-4, Iran and Iraq, Doc. No.1.

${ }^{8}$ There were, however, problems which still needed to be addressed. For example, the Intelligence Estimate pointed to the fact that the living conditions of the population in the countryside remained critical: "The overall position of the peasant in the countryside has not yet changed very much, and efforts to alter attitudes, to raise living standards, and to increase production present a continuing challenge that seems destined to absorb the government's energies and attention for many years to come." Another problem was that the Shah had concentrated the political power in his hands, thus the regime's political base remained narrow: "Over the long term, economic development probably will not provide a satisfactory substitute for greater political participation. Hence, in a few years unrest may again begin to reach significant levels among politically aware elements. In time this could pose serious problems for the regime, particularly if dissent were to find support within the military;" Ibid.

${ }^{9}$ Record of National Security Council Interdepartmental Group for Near East and South Asia Meeting, Washington, April 3, 1969, FRUS, Foreign Relations, 1969-1972, Volume E4, Iran and Iraq, Doc. No. 10.

10 The intensified military presence of both superpowers in the Indian Ocean demonstrated the region's increased strategic significance. The United States had, in fact, acquired the capability to target Soviet territory with missiles launched from submarines (the Polaris A-3 missiles were deployed in 1968). On its part, the Soviet Union had steadily increased its naval presence and searched for ports to station or refuel its forces.

${ }^{11}$ For the United States, Saudi Arabia was an important ally because reliance only on a Persian proxy would further complicate U.S. relations with the Arab world. On the Nixon Doctrine: Robert S. Litwak, Détente and the Nixon Doctrine. American Foreign Policy and the Pursuit of Stability, 1969-1976 (New York: Cambridge University Press, 1984).

${ }^{12}$ Memorandum of Conversation, Washington, April 1, 1969, 10.00 a.m., FRUS, Foreign Relations, 1969-1972, Volume E-4, Iran and Iraq, Doc. No. 8.

${ }^{13}$ Telegram 4183 From the Embassy in Iran to the Department of State, October 13, 1969, 1300Z, FRUS, Foreign Relations, 1969-1972, Volume E-4, Iran and Iraq, Doc. No. 23.

${ }^{14}$ Intelligence Note, U.S. Department of State To the Secretary from George C. Denney Jr., "Shah's Views of Iranian Defense Needs on the Eve of U.S. Visit," October 17, 1969, National Archives (hereafter NA), Nixon Presidential Materials (hereafter NPM), NSC Files, Country files - Middle East, box 601, folder Iran Vol. I (1 of 3).

${ }^{15}$ Ibid. 
${ }^{16}$ Memorandum of Conversation, Washington, April 1, 1969, 10.00 a.m., FRUS, Foreign

Relations, 1969-1972, Volume E-4, Iran and Iraq, Doc. No. 8.

${ }^{17}$ The Shah had, for example, proposed the so-called oil for arms deal. In essence, he asked the U.S. to buy more Iranian oil and, in turn, Iran would use the increased revenues to purchase U.S.-produced armaments. For more details: Telegram 4185 From Embassy in Iran to the Department of State, October 13, 1969, FRUS, Foreign Relations, 1969-1972, Volume E-4, Iran and Iraq, Doc. No. 24. It is important to note that this proposal would never be accepted by the U.S. government, which could not grant special quotas to single countries, and neither directly control the import quotas of the American oil companies.

${ }^{18}$ Memorandum From the President's Assistant for National Security Affairs (Kissinger) to President Nixon, Washington, October 21, 1969, FRUS, Foreign Relations, 1969-1972, Volume E-4, Iran and Iraq, Doc. No. 29.

${ }^{19}$ It is important to note that DOD opposed a commitment on the sale of F-14s and F-15s. Also Kissinger recommended not to make a commitment on these aircrafts; Memorandum From the Deputy Secretary of Defense (Rush) to the President's Assistant for National Security Affairs (Kissinger), Washington, May 18, 1972 and Memorandum From the President's Assistant for National Security Affairs (Kissinger) to President Nixon, Washington, May 18, 1972, FRUS, Foreign Relations, 1969-1972, Volume E-4, Iran and Iraq, Doc. No. 195 and 196.

${ }^{20}$ Henry Kissinger, White House Years (London: Phoenix, 2000), 1263-1264.

${ }^{21}$ The documents complied after the visit reveal that the only condition posed to the sale was that the aircrafts had to be operationally effective before being sold. Once the operational effectiveness of the new planes had been tested in the U.S., the decisions on the purchases and their timing would be left to the Government of Iran.

${ }^{22}$ Memorandum of Conversation, Tuesday, May 30, 1972 - 5:35 p.m. to 6:35 p.m., Saadabad Palace, Tehran, Iran, NA, NPM, NSC files, President's Trip files, box 487, folder: The President's Conversations (Part 2).

${ }^{23}$ Memorandum to the President from Brzezinski, "NSC Weekly Report \# 32," October 14, 1977, Jimmy Carter Presidential Library (hereafter JCL), Donated Historical MaterialBrzezinski Collection (hereafter DHM-BC), Subject file, box 41.

${ }^{24}$ On the importance assigned by Carter to the two regional pillars: Memorandum for the President from Zbigniew Brzezinski, "NSC Weekly Report \# 8," April 9, 1977; for the importance of Iran, as the chief recipient of U.S. arms: Memorandum for the President from Zbigniew Brzezinski, "NSC Weekly Report \# 32," October 14, 1977, JCL, DHM-BC, Subject file, box 41 .

${ }^{25}$ Gaddis Smith, Morality, Reason and Power. American Diplomacy in the Carter Years (New York: Hill and Wang, 1986), 6-7.

${ }^{26}$ On continuity and change during the Carter administration: Scott Kaufman, Plans Unraveled. The Foreign Policy of the Carter Administration (DeKalb: Northern Illinois University Press, 2008), 5-27.

${ }^{27}$ President Carter's human rights rhetoric had put the Shah on the defensive, inducing him to show some signs of reform. In mid-1976, during the U.S. presidential campaign, the Shah took tentative steps to loosen his repressive regime, freeing some political prisoners. However, the pressure that the Iranian leader resented never came. After assuming office, the new administration did not make human rights an issue in its policy towards Iran; Patrick Tyler, A World of Trouble: The White House and the Middle East from the Cold War to the War on Terror (New York: Farrar, Straus and Giroux, 2009), 219.

${ }^{28}$ Cyrus Vance, Hard Choices. Critical Years in America's Foreign Policy (New York: Simon and Schuster, 1983), 321-322. With reference to the events during the Shah's visit to the White House, Vance stated: "these demonstrations (...) perhaps foreshadowed the resurgent opposition to the Shah that was to dominate the following year in Iran. In hindsight, some analysts of the revolution were to call attention to these demonstrations as one of the early signs of the ferment that was to produce the revolution." Clearly, however, at the time the events unfolded, the American leadership decided not to investigate into their motivations and implications.

${ }^{29}$ Bill, The Eagle and the Lion, 227-233.

${ }^{30}$ Citied in Bill, The Eagle and the Lion, 233. 
${ }^{31}$ In 1958, for example, a CIA study assessed that the Shah would be overthrown if he did not initiate a process of internal reform. In 1961, the assessments made for the incoming Kennedy administration viewed a revolution as "imminent;" Bill, The Eagle and the Lion, 125-126, 135-136.

${ }^{32}$ The program included land reform, nationalization of forests, the sale of state-owned enterprises, profit sharing in industry, and electoral rights for women. In 1963, anti-shah riots and demonstrations were repressed by an increasingly autocratic regime. It is important to note that Ayatollah Khomeini was among the leading protesters and was exiled in 1964. On the White Revolution and U.S.-Iranian relations in the 1960s: Bill, The Eagle and the Lion, 132-182; Pollack, The Persian Puzzle, 80-100.

33 Telegram 668 From Embassy in Tehran to the Department of State, February 24, 1970, FRUS, Foreign Relations, 1969-1972, Volume E-4, Iran and Iraq, Doc. No. 49.

${ }^{34}$ Telegram 5142 From Embassy in Iran to the Department of State, December 1, 1970, FRUS, Foreign Relations, 1969-1972, Volume E-4, Iran and Iraq, Doc. No. 102.

${ }^{35}$ Airgram 136 From the Embassy in Iran to the Department of State, May 10, 1971, FRUS, Foreign Relations, 1969-1972, Volume E-4, Iran and Iraq, Doc. No. 126.

${ }^{36}$ Conversation Among President Nixon, Ambassador Douglas MacArthur II and General Alexander Haig, Washington, April 8, 1971, FRUS, Foreign Relations, 1969-1972, Volume E-4, Iran and Iraq, Doc. No. 122.

${ }^{37}$ For example, in January 1972, bombs exploded outside the U.S. mission in Tehran; Telegram 331 From the Embassy in Iran to the Department of State, January 17, 1972, FRUS, Foreign Relations, 1969-1972, Volume E-4, Iran and Iraq, Doc. No. 161. In February 1972, a situation report described sharper protests and dissatisfaction with the Iranian government. Complaints centered on the cost of food, the conviction and execution of protesters, and the corruption of the regime; Telegram 1218 From the Embassy in Iran to the Department of State, February, 29, 1972, Ibid, Doc. No. 169. Moreover, up until Nixon's visit, the administration was receiving assessments which increasingly pointed to the separation between the Shah's leadership and his population; Memorandum From the Director of Central Intelligence (Helms) to the President's Assistant for National Security Affairs (Kissinger), Washington, May 8, 1972, Ibid, Doc. No. 190.

${ }^{38}$ Memorandum for the President from Henry A. Kissinger, "Military Sales Credit for Iran," April 16, 1970, NA, NPM, NSC files, Country files - Middle East, box 601, folder Iran Vol. I (1 of 3).

${ }^{39}$ Pollack, A Persian Puzzle, 106.

${ }^{40}$ Vance, Hard Choices, 316.

${ }^{41}$ Quoted in Bill, The Eagle and the Lion, 258.

${ }^{42}$ Tyler, A World of Trouble, 220-221.

${ }^{43}$ Quoted in Bill, The Eagle and the Lion, 258

${ }^{44}$ Memorandum for the President from Zbigniew Brzezinski, "NSC Weekly Report \# 78," November 3, 1978, JCL, DHM-BC, Subject file, box, 42.

${ }^{45}$ Quoted in Bill, The Eagle and the Lion, 259.

${ }^{46}$ Zbigniew Brzezinski, Power and Principle. Memoirs of the National Security Adviser, 19771981 (New York: Farrar Straus Giroux, 1983), 354.

${ }^{47}$ For a comprehensive study of the internal causes of the Iranian Revolution: Charles Kurzman, The Unthinkable Revolution in Iran (Cambridge: Harvard University Press, 2004).

${ }^{48}$ From the beginning of the Carter administration, it was evident that Secretary of State Cyrus Vance and National Security Adviser Zbigniew Brzezinski, the President's two main foreign policy advisers, had a very different approach to the management of the Cold War relationship with the Soviet Union. Vance's worldview seemed to be consistent with the priority assigned by the President to values and principles, while Brzezinski had a more traditional Cold War attitude towards issues related to National Security. The underlying divergence between Vance and Brzezinski remained latent for the first two years of the administration. But with time, and as the global challenges to the U.S. position multiplied, the initial approach gradually eroded until, towards the end of his term, Carter opted for an explicit return to Cold War attitudes and postures. Accordingly, from 1978 onwards Brzezinski's predominance within the administration gradually 
emerged and his worldview increasingly influenced and defined the presidency's posture.

${ }^{49}$ Brzezinski used this expression to define the area of concern: "If you draw an arc on the globe, stretching from Chittagong (Bangladesh) through Islamabad to Aden, you will be pointing to the area of currently our greatest vulnerability," Memorandum for the President from Zbigniew Brzezinski, "NSC Weekly Report \# 81," December 2, 1978, JCL, DHM-BC, Subject file, box, 42.

${ }^{50}$ Ibid.

${ }^{51}$ Memorandum for the President from Zbigniew Brzezinski, "NSC Weekly Report \# 83," December 28, 1978, JCL, DHM-BC, Subject files, box 42.

${ }^{52}$ For example, Director of CIA Richard Helms stated in the early 1970s: "Ruling out Afghanistan as politically unfeasible, there is no place to which we could transfer these activities were Iran denied us. In time we hope that some of the important coverage now obtained from Iran can be picked up by overhead sensors, but for some years ahead the ground based facilities will remain absolutely essential if we are to keep our knowledge of the Soviet programs up to date;" Memorandum From Harold Saunders of the National Security Council Staff to the President's Assistant for National Security Affairs (Kissinger) Washington, April 16, 1970, FRUS, Foreign Relations, 1969-1972, Volume E-4, Iran and Iraq, Doc. No. 63. Saunders forwarded Helms' memorandum to Kissinger.

${ }^{53}$ The other regional "pillar," Saudi Arabia, was not deemed capable of exercising the role played by Iran because it lacked the military infrastructure and technical expertise and had a ruling family fearful of building a strong military that could endanger the authority of the regime; Charles A. Kupchan, The Persian Gulf and the West. The Dilemmas of Security (Boston: Allen and Unwin, 1987), 70-71.

${ }^{54}$ International Herald Tribune, 20 February, 1979.

${ }^{55}$ Secretary Brown on CBS News, Face the Nation, 25 February, 1979, cited in Kupchan, The Persian Gulf and the West, 85.

56 This refers to Presidential Directive 18 on the necessity of greater deployment capabilities for distant military intervention which dated back to August 1977, but was never implemented; Raymond Garthoff, Détente and Confrontation. American-Soviet Relations from Nixon to Reagan (Washington D.C: The Brookings Institution, 1994), 733.

${ }^{57}$ Memorandum for the President from Zbigniew Brzezinski, "NSC Weekly Report \# 92," March 30, 1979, JCL, DHM-BC, Subject file, box 42.

${ }^{58}$ Garthoff, Détente and Confrontation, 719-726.

${ }^{59}$ Steve Coll, Ghost Wars. The Secret History of the CIA, Afghanistan, and Bin Laden, from the Soviet Invasion to September 10, 2001 (New York: Penguin, 2004), 46.

${ }^{60}$ Kupchan, The Persian Gulf and the West, 99-125.

${ }^{61}$ The "Carter Doctrine;" Jimmy Carter's State of the Union Address, January 23, 1980.

${ }^{62}$ Vance, Hard Choices, 348.

${ }^{63}$ Final Communiqué, NATO Defence Planning Committee, Brussels $13^{\text {th }}-14^{\text {th }}$ May, 1980 , http:/ / www.nato.int/docu/comm/49-95/ c80051 
